\title{
Dose Pack Dosing Unit
}

National Cancer Institute

\section{Source}

National Cancer Institute. Dose Pack Dosing Unit. NCI Thesaurus. Code C62417.

A dosing unit equal to the amount of active ing redient(s) contained in a dosepack. 